\title{
Randall Peerenboom, China's Long March Toward the? Rule of Law, Cambridge University Press, 2002, $673 \mathrm{pp}$.
}

\section{Leïla Choukroune}

\section{(2) OpenEdition \\ Journals}

Electronic version

URL: http://journals.openedition.org/chinaperspectives/365

DOI: 10.4000/chinaperspectives.365

ISSN: 1996-4617

\section{Publisher}

Centre d'étude français sur la Chine contemporaine

\section{Printed version}

Date of publication: 1 June 2003

ISSN: 2070-3449

\section{Electronic reference}

Leilla Choukroune, «Randall Peerenboom, China's Long March Toward the? Rule of Law, Cambridge University Press, 2002, 673 pp. », China Perspectives [Online], 47 | May-june 2003, Online since 10 November 2006, connection on 24 September 2020. URL : http://journals.openedition.org/ chinaperspectives/365; DOI : https://doi.org/10.4000/chinaperspectives.365

This text was automatically generated on 24 September 2020

(c) All rights reserved 


\title{
Randall Peerenboom, China's Long March Toward the? Rule of Law, Cambridge University Press, 2002, $673 \mathrm{pp}$.
}

\author{
Leïla Choukroune
}

\section{EDITOR'S NOTE}

Translated from the French original by Peter Brown

1 If one is to believe the proponents of relativism, any moral philosophy with a universalist claim would be both unrealistic and intolerant. They alone would be able to recognise the irreducible diversity of social moralities and to preserve excellence from Western imperium.

2 This is somehow the impression that we are left with by parts, if not by the whole, of China's Long March Toward the? Rule of Law. In this ambitious 700 page work, Randall Peerenboom, a recognised expert in and practitioner of Chinese law who today teaches Chinese Law at UCLA School of Law, attempts to demonstrate the existence of a "thin rule of law" that is procedural in nature. This concept with "Chinese characteristics" could nevertheless be called that of the rule of law in so far as China may have been able to "develop an alternative version to the Western model of the rule of law". While a "thick theory" or "substantive theory" of the rule of law would incorporate aspects of political morality like forms of government, economic models or the various conceptions of human rights, a "thin theory" would promote the formal or instrumentalist aspects of the rule of law that would rest upon a system of laws that were " general, public, prospective, clear, consistent, capable of being followed, stable and enforced" 
Thus "there must be law to rely on ; where there are laws, they must be followed; laws must be strictly enforced; and violations of law must be corrected" (youfa keyi, youfa bi $y i$, zhifa bi yan, weifa bi jiu). This legal credo adopted by the Chinese Communist Party back in 1978 would attest to the willingness of the government to work progressively towards an original form of the rule of law based on a fundamental reworking of a legal system inherited from Maoism and ill-adapted to the economic developments to come. The legal revolution on the move The hyper activity of legislation characteristic of reformist China is deemed to have led therefore to the development of the famous yifa zhiguo, a government in tune with the law, that can only be understood by reference to the second variable of the equation, jianshe shehuizhuyi fazhiguo, that is the establishment of a Socialist rule of law, a formula that was itself consecrated by the constitutional amendments of 1999. Indeed, the writer gives a very good description and in-depth analysis of the main transformations undergone by the Chinese legal system over the past twenty-five years. To begin with, in the first two chapters of his work, he does this according to a historical approach, before adopting the tack of dividing his subject up into several main areas: the legislative system, the judiciary, the legal profession and administrative law regime. The final chapters of China's Long March Toward Rule of Law are devoted to more philosophical developments dealing with the relation between the rule of law, economic growth and democracy. The book closes with a certain number of recommendations intended for states which, in the likeness of the United States-or the Europeans for that matter-, might be tempted to promote the rule of law in China.

Randall Peerenboom's work clearly tends towards a certain exhaustiveness ${ }^{2}$, based as it is on many theoretical references, being very well documented and hence having a rich critical apparatus. One can only regret, however, that the latter is not more easily accessible and that it often remains a little confused in its presentation. It is true that all the arguments and counter-arguments of the defenders of the rule of law and its Western and Chinese opponents are carefully sifted through as if to give a more solid foundation to this attempt at defining a new theoretical framework. However, the writer could well have eliminated a number of pages without any loss, as the general thesis seems to us to be often diluted in descriptions that do not allow any real account to be taken of the positions of the doctrine on the relation between right and economic development and even more glaringly between democracy and the rule of law ${ }^{3}$.

Rule of law versus democracy

6 At the risk of being accused of "liberal ethnocentrism with universalising tendencies", we must strenuously affirm here that the rule of law and democracy are to our way of thinking two principles that are consubstantial. Indeed, there exists an ontological link between these two ideas that cannot be ignored. Beyond the 1948 Universal Declaration of Human Rights, the 1966 Pact relating to Civil and Political Rights or the European Convention on Human Rights, it is worth quoting the Copenhagen Declaration of June 29th 1990, article 3 of which states that "democracy is integral to the rule of law" or, more recently, the Preamble to the Charter on the Fundamental Rights of the European Union which emphasises that "the Union is based on the twin principles of democracy and the rule of law".

7 It is therefore absolutely unacceptable to read, for example, that "Democracy therefore implies rule of law, but not vice-versa" or again that the rule of law may coexist with non democratic and non liberal forms of government ${ }^{4}$. Moreover, the writer purports 
to demonstrate that the construction of a state where the rule of law obtained could be conceived as a necessary stage on the way to democratisation. This need not mean, however, that China would end up as a liberal democracy, but rather as a "non liberal", "soft authoritarian" or even "communitarian" form of democracy. Thus "a one-party socialist regime in which the Party plays a major role" would " a single party socialism in which the Party plays a leading role is in theory compatible with the rule of law, albeit not a Liberal democratic version of rule of law" 5 .

In this sense, why not suppose that the amendments to the statutes of the Chinese Communist Party at its 16th Congress are part of this same reforming logic, in so far as they aim to put in place a "socialist democracy" governed in perfect complementarity by the "law" (yifa zhiguo) and "virtue" (yide zhiguo). The codification of comrade Jiang Zemin's "innovative thought for the 21st century", whose main thrust was formulated in 2000 in the "theory of the three representatives" (sange daibiao) is therefore supposedly to lead us gradually towards the rule of law Chinese-style, the first stage in the process of setting up a democracy, also Chinese-style.

9 If there is no reason to be surprised by the fact that China may create a political model that is unique to itself and is not therefore the transposition of pre-existing Western models, it is nonetheless impossible to empty of their meaning legal and philosophical concepts like those of the rule of law and democracy in the name of a benevolent denunciation of a certain ethnocentrism ${ }^{6}$. Through an excessive desire to take account of Chinese specificities, Randall Peerenboom indirectly comes to trample on the very foundations of principles with a universal vocation.

Rule of law and related concepts

Having founded legality and its jurisdictional control, the rule of law aims as it were to circumscribe the power of the state through law and to guarantee the protection of the rights of the person. It forms a whole and cannot therefore be carved up without seeing its impact reduced and its meaning tainted. The rule of law is also characterised by the separation of powers, the independence of the judiciary, the existence of a control over constitutionality and over the legality of administrative acts.

11 The polysemy and the ambiguity of the term "rule of law" is no longer to be proved, however. The English term "rule of law", and the French and German terms, Etat de droit and Rechtsstaat, respectively, are in fact concepts with quite different acceptations, and everything suggests that it is impossible to translate the "rule of law" which Randall Peerenboom writes about by the French term "Etat de droit"7. While the "rule of law" refers only to a formal system of law that guarantees a certain legal security, there certainly does exist in China, and especially in the economic sphere, a tendency towards the rationalisation of legal practices and even towards a certain "juridicisation" of society that attests to a popular consciousness of the existence of rights and a greater aspiration to justice. But the whole ambiguity of the writer's thesis is that he does not seem to be content with a mere formal definition of the rule of law in any procedural sense. He seeks rather to define it with regard to democracy in order to prove its ability to exist within an authoritarian regime. This involves a sort of perversion or at least a confusion of genres that is prejudicial to the overall demonstration and finally makes the idea according to which China supposedly broke with an instrumentalist conception of the law somewhat less than convincing.

12 This work by an astute expert of the Chinese legal field, which to its credit takes a certain number of risks in terms of formulating new ideas, is not, however, for 
everyone. Indeed, a reader with insufficient legal and political background knowledge could easily let himself or herself be led astray by the dangerous sirens of a revisited culturalism.

\section{NOTES}

1. See page 3 of the Introduction and Chapter 3 (especially p. 65) in which Randall Peerenboom refers inter alia to the views developed by Lon Fuller in The Morality of Law, New Haven, Yale University Press, 1976.

2. Randall Peerenboom frequently positions himself, in fact, in relation to the thinking of L.A. Hart, John Rawls, Joseph Raz, Jürgen Habermas or indeed Joseph Stiglitz, something that is quite unusual in works dealing with Chinese law, and hence worthy of note.

3. See Chapters 10 and 11 and, especially, the exposition of liberal democracy, p. 533 and ff.

4. See p. 515 and ff.

5. See p. 10 and Chapter 5 "Retreat of the Party and the State". In this perspective, Randall Peerenboom sets himself apart from many other experts of Chinese law who, in the model of Stanley Lubman, see in the current ideological straitjacket an insurmountable hurdle to the emergence of any real state governed by the rule of law. See in this connection footnote 30, p. 24.

6. This tendency, one that we had already detected in The Limits of the Rule of Law in China, edited by Karen G. Turner, James V. Feinerman and R. Kent Guy, actually underlies the whole exposition.

7. See the excellent thesis by Luc Heuschling, Etat de droit, Rechtsstaat, Rule of Law, Paris, Dalloz, 2002, 739 pp. 